\title{
The application of empty fruit bunch (EFB) fibers of oil palm for the development of light structure materials and products
}

\author{
Bustami Syam ${ }^{1, *}$, Maraghi Muttaqin ${ }^{1}$, Mawardi ${ }^{2}$, Fachrur Rozi ${ }^{2}$, Martgomi, and James \\ Hutagalung \\ ${ }^{1}$ Impact and Fracture Research Center, Department of Mechanical Engineering, Faculty of \\ Engineering, Universitas Sumatera Utara \\ ${ }^{2}$ Graduate Student, Mech. Engineering Study Program, Universitas Sumatera Utara \\ ${ }^{3}$ Undergraduate Student, Department of Mechanical Engineering, Universitas Sumatera Utara
}

\begin{abstract}
We have been involved in developing the use of EFB fibers for several light structural products, such as speed bumps, parking stoppers, helmets, and horse shoes. This paper presents our current research work on parking bumper made of EFB fibers to be utilized for power generation. The products are designed and produced in full scale covering the whole width of vehicles passing over the bumpers. The ideas are how to reserve kinetic energy harvested from the vehicles to convert into electricity to be stored in a battery. To obtain a structural integrity-proof material, the speed bumps were subjected several tests, e.g. static and impact tests as well as live body test using the kinetic energy obtained from vehicles pass over the speed bumps. For this, a speed bump station parallel to street zebra-cross was prepared. It was obtained that A-5 concrete foam type is suitable for $3 \mathrm{~B}$ class road. The structural response of speed bumps were checked using ANSYS 17.0.
\end{abstract}

\section{Introduction}

Palm oil industries processing crude palm oil (CPO) or kernel palm oil (PKO) produce a huge capacity of biomass in terms of empty fruit bunch (EFB) and tree trunk, and leaves. Utilization of the energy that comes from the by-products in the oil palm industry can be done by using biomass and biogas technology. EFB fibers, for instance, has been used for strengthening polymeric and concrete materials [1-10]. The EFB cannot directly be used. A series of processing of the EFB to reduce oil contents are necessary. Ready used fibers may reinforce the concrete or polymeric based materials. In our laboratory, some new materials reinforced with EFB fibers have been widely used for several light structures due to it light weight but they are still strong enough to sustain external loading.

In this paper, we extend our research on developing a large scale speed bump the concrete foam reinforced EFB is used as a speed bump to generate electricity. The speed bump is placed on to a mechanical system, as shown in Figure 1. Mechanically, the translatory motion

\footnotetext{
* Corresponding author: bstsyam@gmail.com
} 
of speed bump is changed into circular motion at a fly wheel connected to electrical generation apparatus. With this connection, the speed bump works well when accepting the weight of the vehicle weight (speeds up to $10 \mathrm{~km} / \mathrm{h}$ ).

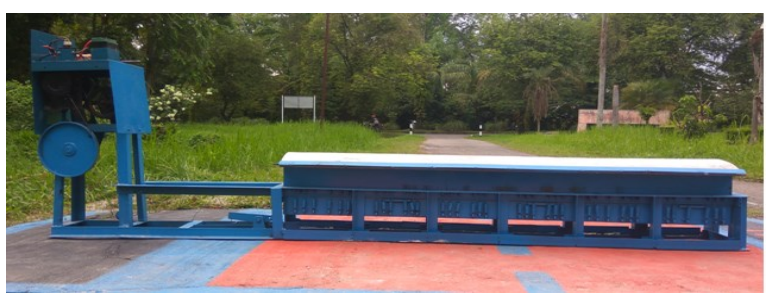

Fig. 1. Power generation apparatus using speed bump.

\section{Materials and method}

\subsection{Material and speed bump fabrication}

In our previous research we have developed classes of confoam materials [1, 10]. In this study, as per conclusion and suggestion in our previous research [10], we choose A5 typeconfoam to produce a full scale-speed bump. The physical and mechanical properties of the material are shown in Table 1.

Table 1. Confoam mechanical properties (MP3EI research report).

\begin{tabular}{ccccc}
\hline $\begin{array}{c}\text { Type } \\
\text { spesimen }\end{array}$ & Suc(MPa) & Sut, (MPa) & $\square$ & $\begin{array}{c}\text { E } \\
\text { (MPa) }\end{array}$ \\
\hline A5 & 2.1 & 0.18 & 0.2 & 10.1 \\
\hline
\end{tabular}

The speed bumps were produced in the accordance with the geometry that meets the requirements set forth in Kemenhub (Ministry of Transportation decree), number 3, 1994, as shown in Figure 2. Several parts of the speed bump geometry, i.e., the upper surface configuration and the base speed bump, had been revised to meet a structure suitable for the passing vehicle load. In this paper, we propose geometry and dimensions as shown in Figures 3. The main dimensions of the speed bump are as follows: (a) type 1 (length, $\mathrm{L}=1900 \mathrm{~mm}$, witdh, $\mathrm{w}=400 \mathrm{~mm}$, thickness, $\mathrm{t}=52 \mathrm{~mm}$ ); (b) type 2 (length, $\mathrm{L}=1900 \mathrm{~mm}$, width, $\mathrm{w}=$ $400 \mathrm{~mm}$, thickness, $\mathrm{t}=40 \mathrm{~mm})$. The dimensions are difference from those of we have published in our previous research work [10].

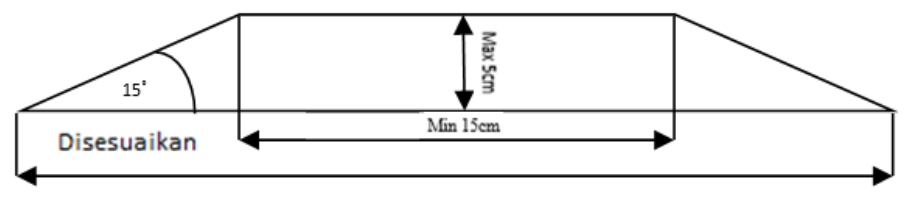

Fig. 2. Kemenhub 2 year 1994 (Ministry of Transportation standard size). 


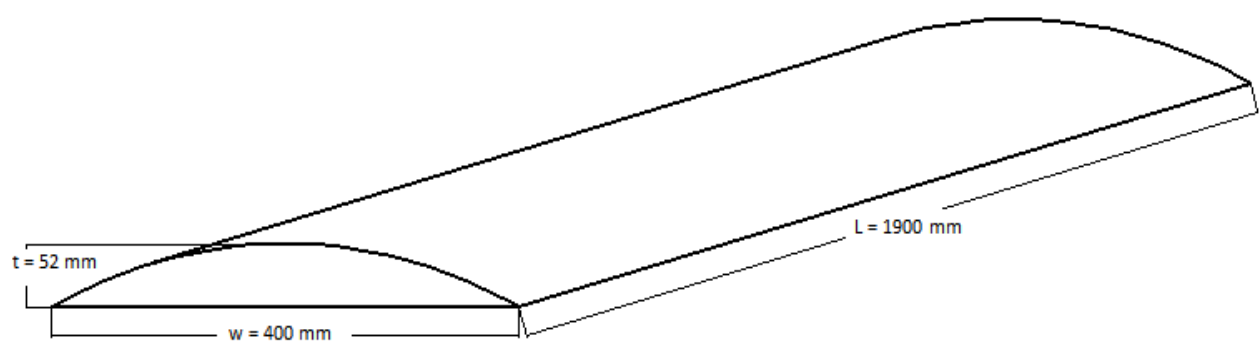

(a)

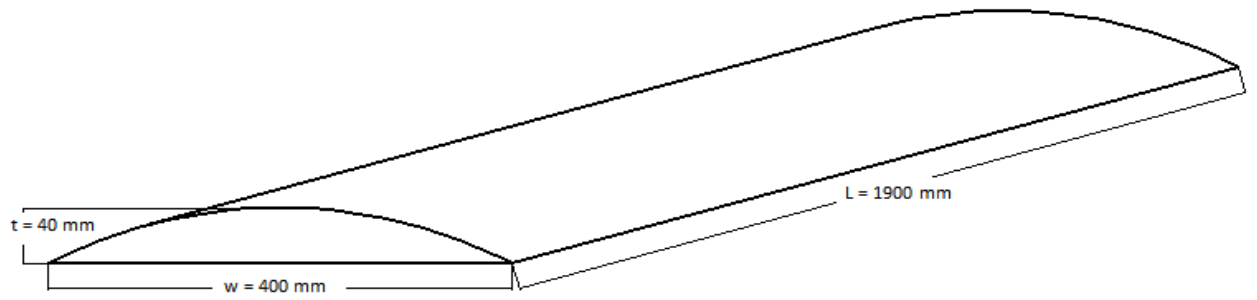

Fig. 3. Geometry and dimensions of the speed bump.

\subsection{Method}

As shown in Figures 1 and 2, the speed bump is placed on a steel bed attached to the top of the mechanical system of power generation. The speed bump accepts the load from the wheels of cars that pass through it. Thus, the speed bumps are designed to be able to receive static and dynamic loads in such a way as to meet technical and manufacturing requirements. For this, we selected newly developed materials at our strong enough to withstand both static and impact loads (not reported in this paper). A work station was prepared to place the mechanical system as well as the speed bumps. The static load simulated a station is obtained from vehicles pass over it in range of $5-10 \mathrm{~km} /$ hour.

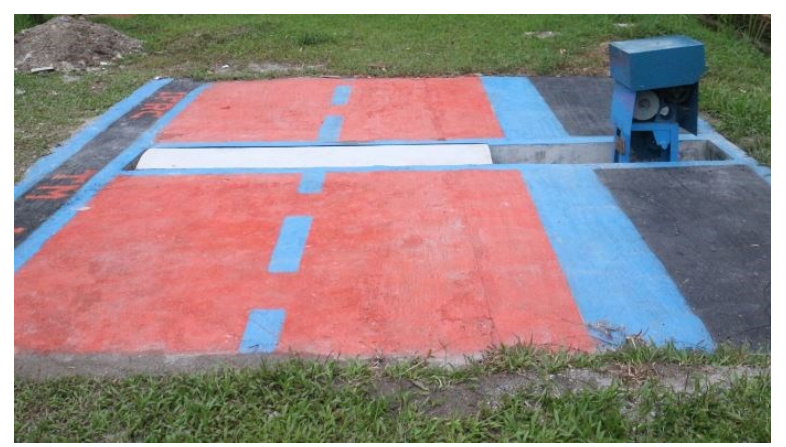

(a) 


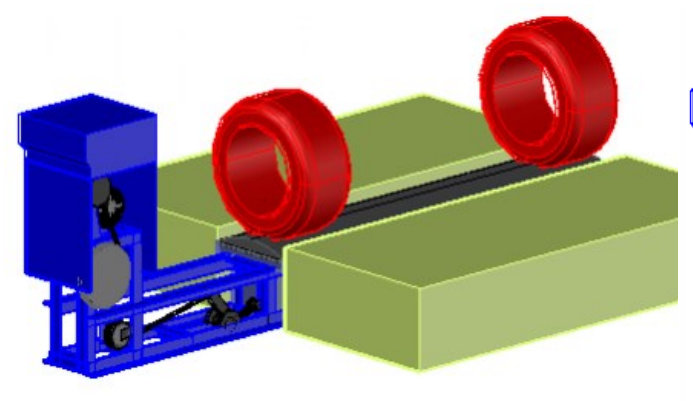

(b)

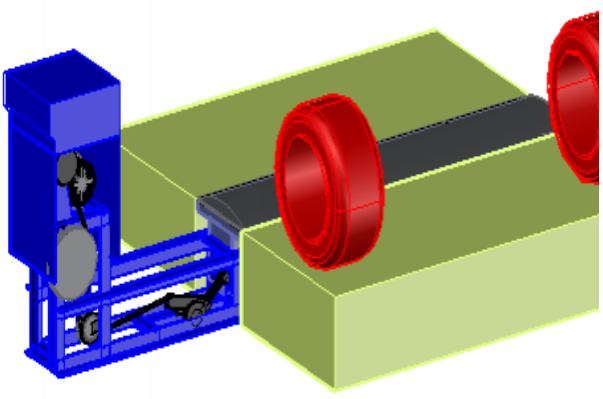

(c)

Fig. 4. Experimental setting of speed bump power generation vehicle entering the speed bump (b) vehicle on top the speed bump.

\section{Numerical simulation}

\subsection{Geometry and load model}

The load, applied to the speed bump contact area (Figure 5) representing the vehicle-tyre track, is obtained from a quarter of the total vehicle weight allowed for class III road. Numerical calculations are focused on stress distributions at $\mathrm{x}, \mathrm{y}$, and priciple points using commercial FEM software, with 3-D elements. For both models we also calculated vonMises stress. Let's examine the stress contours of the models one by one.

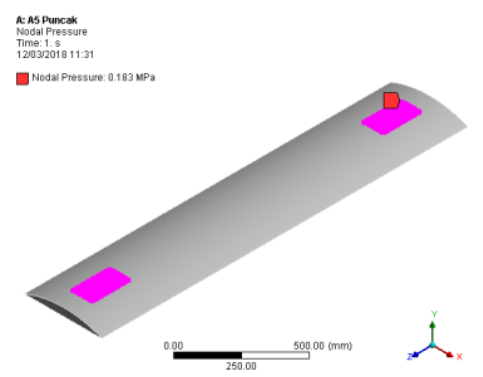

Fig. 5. Loading model at contact area.

\subsection{Contours of stress}

We focus the discussions on the stress contours on $\mathrm{x}, \mathrm{y}, \mathrm{z}$, and principle directions both for type 1 and 2 of the speed bump models. The $x$ and $z$ directions may show the initiation of speed bump failures. All calculations as shown in Figure 6 are presented in Table 2. It is interesting to observe that the model reduces the stresses in all directions. The stress contour in the area remote from the contact surface show us that it is uniformly distributed in which for all cases the tensile stress is lower than that of tensile strength of the speed bump material. However, for a series of tests conducted in our work station with higher velocity of vehicles the failure may also occur (Figure 8). We may say that the impact tensile strength of the concrete foam should also be known (our current research).

Let us check normal stress responses in $\mathrm{z}$ direction on the entry base and the upper surface of the speed bump type 1 and 2. It is obviously indicated that the $\mathrm{z}$ direction stress is lower at the entry base and then slightly increase when the tyre approaching the top surface of the 
speed bump. However, it is interesting to note that the height of the speed bumps are not significantly increase the equivalent stresses.

From Figure 9. We observe that the von Mises stress is quite low compared to the static speed of type 1 bump material. The results conclude that the case of the speed bump type is susceptible to load resistance. Thus, they will have the potential to be used to accelerate power generation.

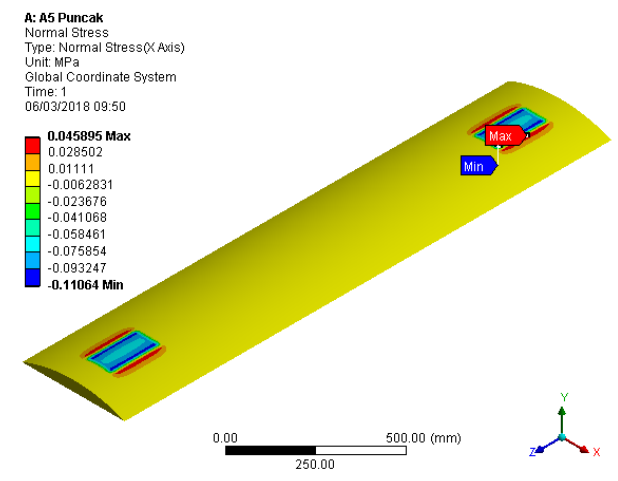

(a)

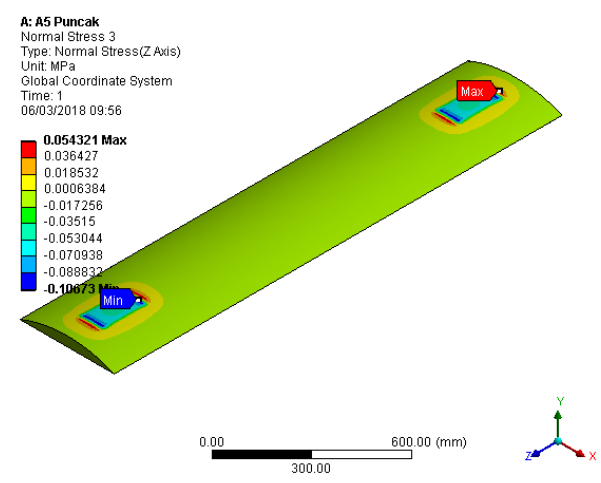

(c)

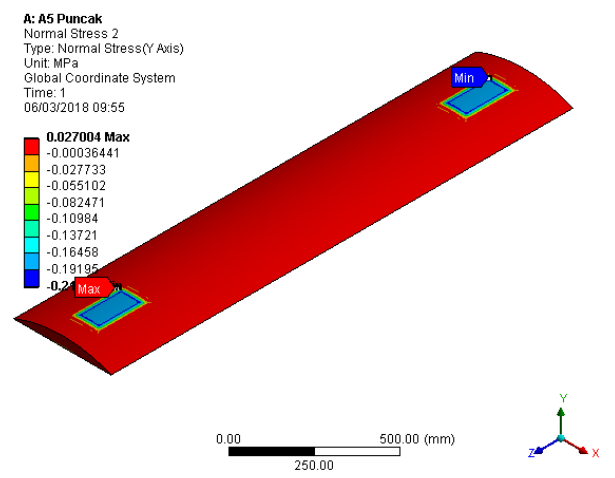

(b)

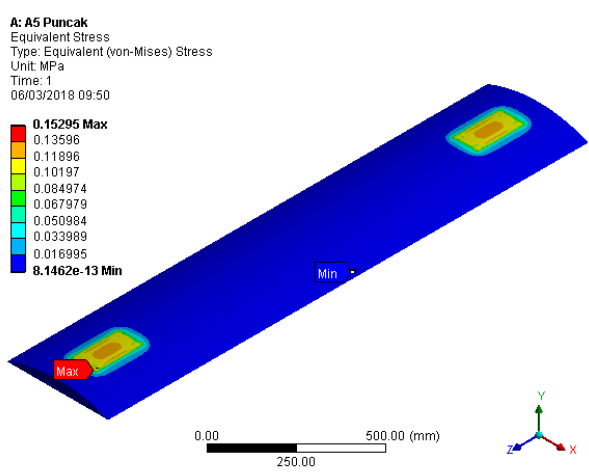

(d)

Fig. 6. Stress contour due to loading at top surface for type 1 model.

(a) Normal stress in $\mathrm{x}$ direction (b) Normal stress in $\mathrm{y}$ direction

(c) Normal stress in $\mathrm{z}$ direction (d) Equivalent stress

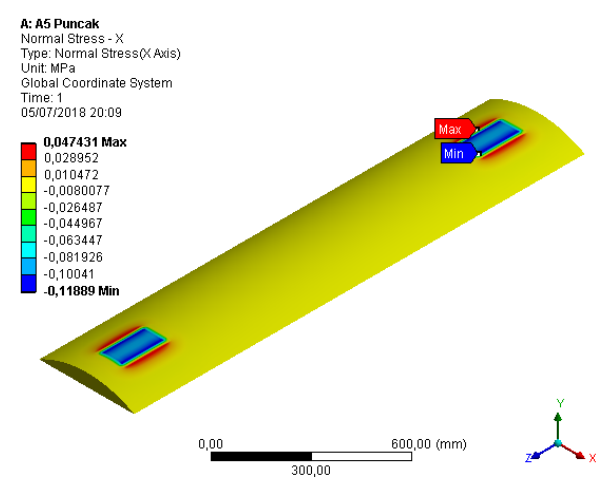

(a)

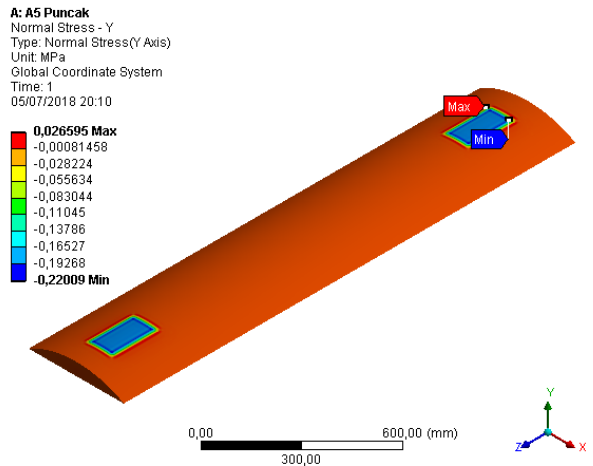

(b) 


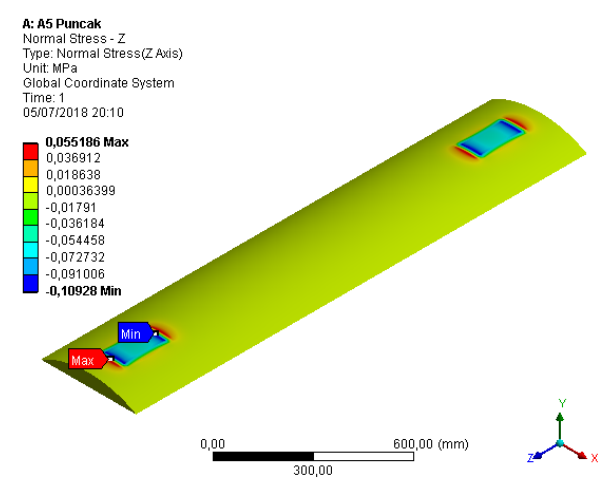

(c)

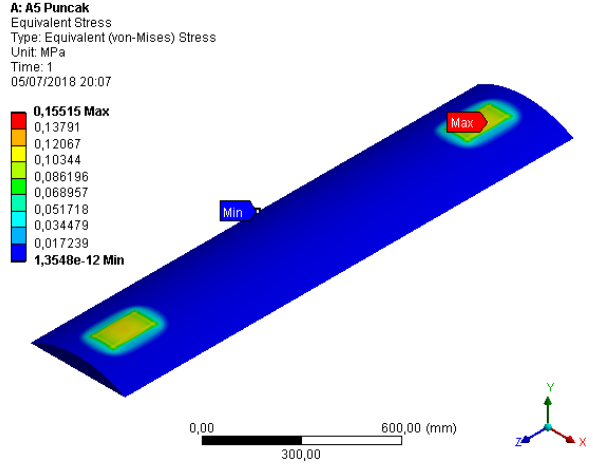

(d)

Fig. 7. Stress contour due to loading at top surface for type.

(a) Normal stress in $\mathrm{x}$ direction (b) Normal stress in $\mathrm{y}$ direction

(c) Normal stress in z direction (d) Equivalent stress

Table 2. Stress calculation at certain locations on speed bump ( $\mathrm{h}=40 \mathrm{~mm})$.

\begin{tabular}{ccccc}
\hline $\begin{array}{c}\text { Speed bump } \\
\text { material/Contact } \\
\text { area }\end{array}$ & $\begin{array}{c}\text { Equi. Stress } \\
\text { (MPa) }\end{array}$ & $\begin{array}{c}\text { Stress in } \mathbf{x} \\
\text { axis (MPa) }\end{array}$ & $\begin{array}{c}\text { Stress in y } \\
\text { axis (MPa) }\end{array}$ & $\begin{array}{c}\text { Stress in } \mathbf{z} \\
\text { axis (MPa) }\end{array}$ \\
\hline A5/Entry base* & 0.164 & 0.033147 & 0.021 & 0.0357 \\
A5/Top surface & 0.152 & 0.045 & 0.027 & 0.054321 \\
\hline
\end{tabular}

Table 3. Stress calculation at certain locations on speed bump $(\mathrm{h}=52 \mathrm{~mm})$.

\begin{tabular}{ccccc}
\hline $\begin{array}{c}\text { Speed bump } \\
\text { material/Contact } \\
\text { area }\end{array}$ & $\begin{array}{c}\text { Equi. Stress } \\
\text { (MPa) }\end{array}$ & $\begin{array}{c}\text { Stress in } \mathbf{x} \\
\text { axis (MPa) }\end{array}$ & $\begin{array}{c}\text { Stress in } \mathbf{y} \\
\text { axis (MPa) }\end{array}$ & $\begin{array}{c}\text { Stress in } \mathbf{z} \\
\text { axis (MPa) }\end{array}$ \\
\hline A5/Entry base* & 0.1748 & 0.0334 & 0.0205 & 0.0373 \\
A5/Top surface & 0.1551 & 0.0474 & 0.0265 & 0.0551 \\
\hline
\end{tabular}

*Note: computer simulation not shown

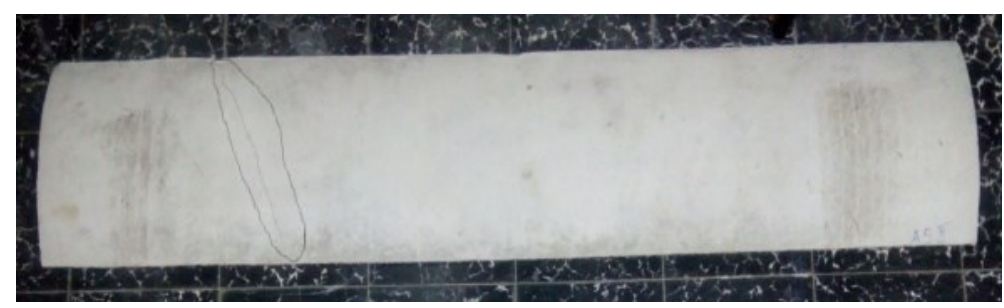




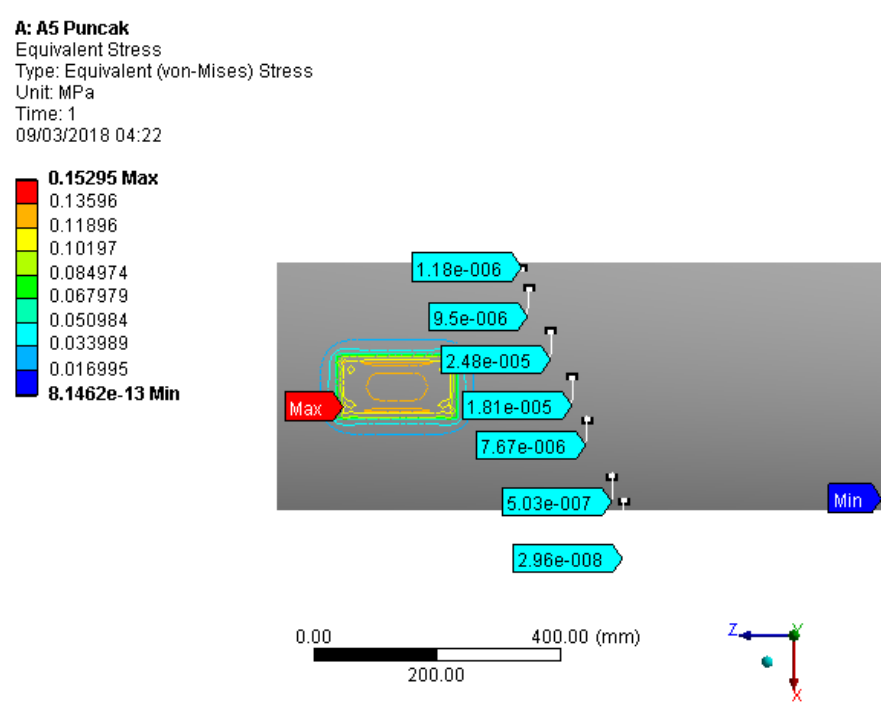

Fig. 8. Specimen failures and the corresponding stresses.

\section{Conclusions}

This paper discussed the analysis of speed bump made of concrete foam composite which is used to generate electrical power. The concrete foam is reinforced with oil palm EFB fibers. Two models were proposed, they are: (a) type 1 (length, $\mathrm{L}=1900 \mathrm{~mm}$, witdh, w $=400 \mathrm{~mm}$, thickness, $\mathrm{t}=52 \mathrm{~mm}$ ); (b) type 2 (length, $\mathrm{L}=1900 \mathrm{~mm}$, witdh, $\mathrm{w}=400 \mathrm{~mm}$, thickness, $\mathrm{t}=40 \mathrm{~mm}$ ). To observe the structure integrity of the speed bumps the models were analyzed using a FEM-based numerical softwares, ANSYS17.0. It was obtained that the $\mathrm{z}$ direction stress is lower at the entry base and then slightly increases when the tyre approaching the top surface of the speed bump. However, it is interesting also to note that the height of the speed bumps are not significantly increases the equivalent stresses.

From Figure 8, we observe that the von Mises stress is quite low compared to the static strength of the speed bump material. The results conclude that concrete foam composite may also be potential for use as power generation speed bumps.

\section{Acknowledgements}

The authors acknowledge the research fund obtained from USU TALENTA scheme 2018.

\section{References}

1. B. Syam, B. Wirjosentono, S. Rizal. Pengembangan bahan komposit busa polimer (polymeric foam composite) diperkuat serat tandan kosong kelapa sawit (TKKS) untuk pembuatan berbagai produk industri transportasi dan olah raga. Final Report PENPRINAS MP3EI, DIKTI, (2013)

2. A. Irwan, B. Syam, W.S. Basuki. Analisa respon mekanik genteng dari bahan confoam diperkuat serat tkks akibat beban impak hujan es. Prosiding Seminar DIES USU, (2016) 
3. B. Syam, A. Sebayang, I. Gunawan, M. Muttaqin, H. Darmadi, W.S. Basuki, M. Sabri, S. Abda. Mechanical response of open channel cover made of concrete foam due to external loadings. Journal of Physics: Conference Series 801 012097, (2017)

4. B. Syam, M. Muttaqin, D. Hastrino, A. Sebayang, W.S. Basuki, M. Sabri, S. Abda. Analysis of power generating speed bumps made of concrete foam composite. IOP Conference Series: Materials Science and Engineering 180, 1, (2017)

5. B. Syam, A. Sebayang, S. Sebayang, M. Muttaqin, H. Darmadi, W.S. Basuki, M. Sabri and S. Abda. Design and production of stopper made of concrete foam composite used for open channel conduit cover and parking bumper. IOP Conference Series: Earth and Environmental Science 126 012053, (2018)

6. M Sabri, J. Lauzuardy, B. Syam. Design mechanic generator under speed bumper to support electricity recourse for urban traffic light. IOP Conference Series: Earth and Environmental Science 126012014 , (2018)

7. D. Hastrino, I. Pasi, M. Muttaqin, B. Syam, W.S. Basuki, M. Sabri, S. Abda. Analisa struktur speed bump paduan bahan concrete foam dan polymeric foam dengan variasi rongga menggunakan sofware Ansys 14.5. Prosiding Seminar DIES USU, (2016)

8. S. Pranoto. Desain dan pembuatan kerucut lalu lintas dan bahan polymeric foam diperkuat serat tandan kosong kelapa sawit. Universitas Sumatera Utara, (2011)

9. Y. Muhammad. Desain dan pembuatan helmet sepeda bahan komposit poymeric foam diperkuat serat TKKS. Universitas Sumatera Utara, (2011)

10. Ahmadyani S. Performasi respon mekanik bola golf polymeric foam yang diperkuat serat tandan kosong kelapa, (2012) 